Open Access

\title{
Japanese Encephalitis: Epidemiology and Current Perspectives in Vaccines
}

\author{
Manica Balasegaram and Daniel Chandramohan*
}

London School of Hygiene \& Tropical Medicine, Keppel Street, London WC1E 7HT, UK

\begin{abstract}
Japanese encephalitis is a major cause of encephalitis in Asia. An estimated 50000 cases occur in largely rural areas of the south and east Asian region resulting in significant morbidity and mortality. While the disease has declined in Japan, South Korea, Thailand and China, it has extended in other parts of the region, including India and Nepal. Diagnosis of the disease is largely based on clinical signs and symptoms, and treatment remains supportive. Further work is needed to provide rapid reliable diagnostics and improved surveillance. Vaccination is the mainstay of preventing serious disease in humans. The mouse brain derived vaccine is the most widely used vaccine though there are safety concerns. A live (SA 14-14-2) vaccine is increasingly being used though regulatory issues around production need to be resolved. There are also promising new vaccines undergoing clinical trials that show potential for wide scale use. Vaccine schedules, surveillance of adverse events, and setting up effective vaccination programmes are important issues that need addressing to maximise the impact of the available vaccines.
\end{abstract}

\section{INTRODUCTION}

Japanese encephalitis (JE) is a zoonotic arboviral infectious disease affecting South and South-east Asia. It is estimated that 50,000 cases and over 10,000 deaths occur annually though this is considered an under-estimate [1]. Over 3 billion people including 700 million children live in areas at risk. The high-risk group for JE is 1-15 year-old children [2]. $\mathrm{JE}$ is a major public health concern in endemic areas and vaccines are the mainstay for the control of JE. There are currently 3 vaccines available for the prevention of JE. In spite of having an ad-hoc vaccination programme in the last six decades, 10.5 million children were estimated to have been infected, resulting in 3 million deaths and 4 million long-term disabilities, making JE the most important childhood viral encephalitis [2]. This implies that the past vaccination strategies have limitations as a successful disease control measure. Therefore a public health perspective into understanding our current practices in JE prevention through vaccination would be of importance. We present here an overview of the epidemiology of JE, assess the potential impact of the major vaccines (primarily the mouse brain derived inactivated (MBDI) and live attenuated SA 14-14-2 vaccines), and discuss limitations and future perspectives of JE vaccines in clinical development.

\section{METHODS}

Articles on JE epidemiology and vaccines published from 1982 to June 2007 were identified using Pubmed (Medline) and Google scholar search engines and search terms, 'Japanese encephalitis' with either 'epidemiology' or 'Vaccines'. This search The websites of WHO and PATH were also searched accordingly. A manual review of the references of key articles found from the primary search was additionally

*Address correspondence to this author at the London School of Hygiene \& Tropical Medicine, Keppel Street, London WC1E 7HT, UK;

E-mail: daniel.chandramohan@1shtm.ac.uk undertaken, principally for textbooks and older articles not available on line. There were 2676 papers on JE but only 535 had some information on JE vaccine or epidemiology. However, only 70 studies that had reported data on JE vaccine efficacy, effectiveness and or cost effectiveness were included in the review of JE vaccines. Studies excluded were mainly reports of pre-clinical trials or published in languages other than English.

\section{EPIDEMIOLOGY}

\section{Infectious Agent \& Immunology}

JE belongs to the genus Flavivirus of the family Flaviviridae. JE belongs to the same serological group as Murray Valley encephalitis virus, West Nile virus and St.Louis virus, all of which are transmitted by Culex mosquitoes. JE is a single stranded positive sense RNA virus. Its structure consists of a genome of 10,976 bases surrounded by a nucleocapsid and lipid membrane. Within the membrane are the envelope (E), membrane (M) and precursor $\mathrm{M}$ (prM) proteins [3]. Other proteins include the NS1-5. The E protein is of particular importance as it binds to cell receptors and initiates infection. Neutralising antibodies to the $\mathrm{E}$ antigen protein plays a role in fighting infection and preventing disease [3,4]. Neutralising (NT) antibodies provide evidence of established immunity as demonstrated in efficacy trials and animal studies, and this relationship appears linear [5]. An antibody threshold level for protection at a 1:10 dilution in a $50 \%$ plaque reduction neutralising assay (PRNT) has recently been recommended by a group of WHO consultants $[5,6]$. Cell mediated immunity has also been demonstrated to play a role in protection against JE [7].

\section{Transmission \& Reservoir}

$C x$. tritaeniorhynchus and vishnuii are the principal vectors, breeding in stagnant pools and rice fields. The disease tends to occur in rural areas with transmission from AprilOctober in temperate climates or during rainy seasons in 
tropical/ subtropical areas. However irrigation may allow continuation of transmission into the dry season [8]. Humans, like horses are considered dead end hosts to the disease due to insufficient viraemia. Pigs and 'wading birds' are principal amplifying hosts that are crucial for viral multiplication [2]. In pigs the disease causes spontaneous abortions though rarely causes disease in adults [9]. Monitoring of antibody levels in pigs and isolation of the virus in mosquitoes has shown a rise in mosquito density, proceeded by a rise in antibody titres in pigs, followed by infection in humans over a transmission season [10-12]. This limits control measures as it is not feasible to use insecticides in vast areas of rural land (excepting emergencies) while there is limited incentives for farmers to vaccinate their animals [9]. The effectiveness of other forms of vector control like insecticide treated bed nets to control JE has not yet been evaluated. This leaves human vaccination as a mainstay in protecting individuals and populations from infection. However the existence of amplifying hosts means that any vaccination strategy must be sustained for indefinite periods and that there will be little herd immunity conferred by mass vaccination.

\section{Clinical Features, Diagnosis \& Treatment}

It is estimated that only 1 in 250 infections result in clinical illness [13]. Incubation period is around 6-14 days. Clinical infection has a spectrum varying from fever and aseptic meningitis to seizures (especially in children), paralysis (spastic or flaccid) and coma. ${ }^{14}$ Frequent and long-term neurological and psychiatric sequalae is common in up to $40 \%$ of cases [9,12]. Surveillance systems for suspected cases have formed case definitions of fever with either meningeal symptoms and signs, or cortical irritation, or altered consciousness, or cranial nerve symptoms or extra/ pyramidal signs [12]. A lack of common surveillance standards and focus on encephalitis means an under appreciation of possibly a wider spectrum of disease and hence under-estimation of true disease burden [1,9].

The importance of confirmation of suspect cases to identify outbreaks was demonstrated by the Nipah virus epidemic in Malaysia in 1998-99 [14,15]. Confirmation of diagnosis remains serology with IgM capture ELISA (serum or CSF) which has $68-100 \%$ sensitivity for CSF in the week postonset [1]. There may be cross reactivity with other Flavivirus and a positive test is obtained post-vaccination. Other diagnostics include conventional antibody assays on paired sera, dot-blot IgM assay and less usefully, viral detection in autopsy brain tissue or CSF [8]. Tsai notes that from 196877 to $1978-87$, milder cases and less morbidity was seen with implementation of vaccination. This would emphasise the need for more and simpler laboratory diagnosis [9]. A similar picture was seen in Kurnool, India where case fatality dropped from $50.4 \%$ in 1994 to $12.9 \%$ in 2003 [1]. However, the experience from Taiwan suggested that the vaccine does not modify disease outcome [12].

Clinical management of disease remains supportive with control of fever and seizures, good nursing care, nutrition and hydration. Management of intracranial hypertension with ventilation and mannitol may not always be feasible in the resource limited health care setting. Studies on both dexamethasome and Interferon 2 alfa have also shown no clinical benefit $[16,17]$. Limitations in clinical management further emphasises the importance of vaccination.

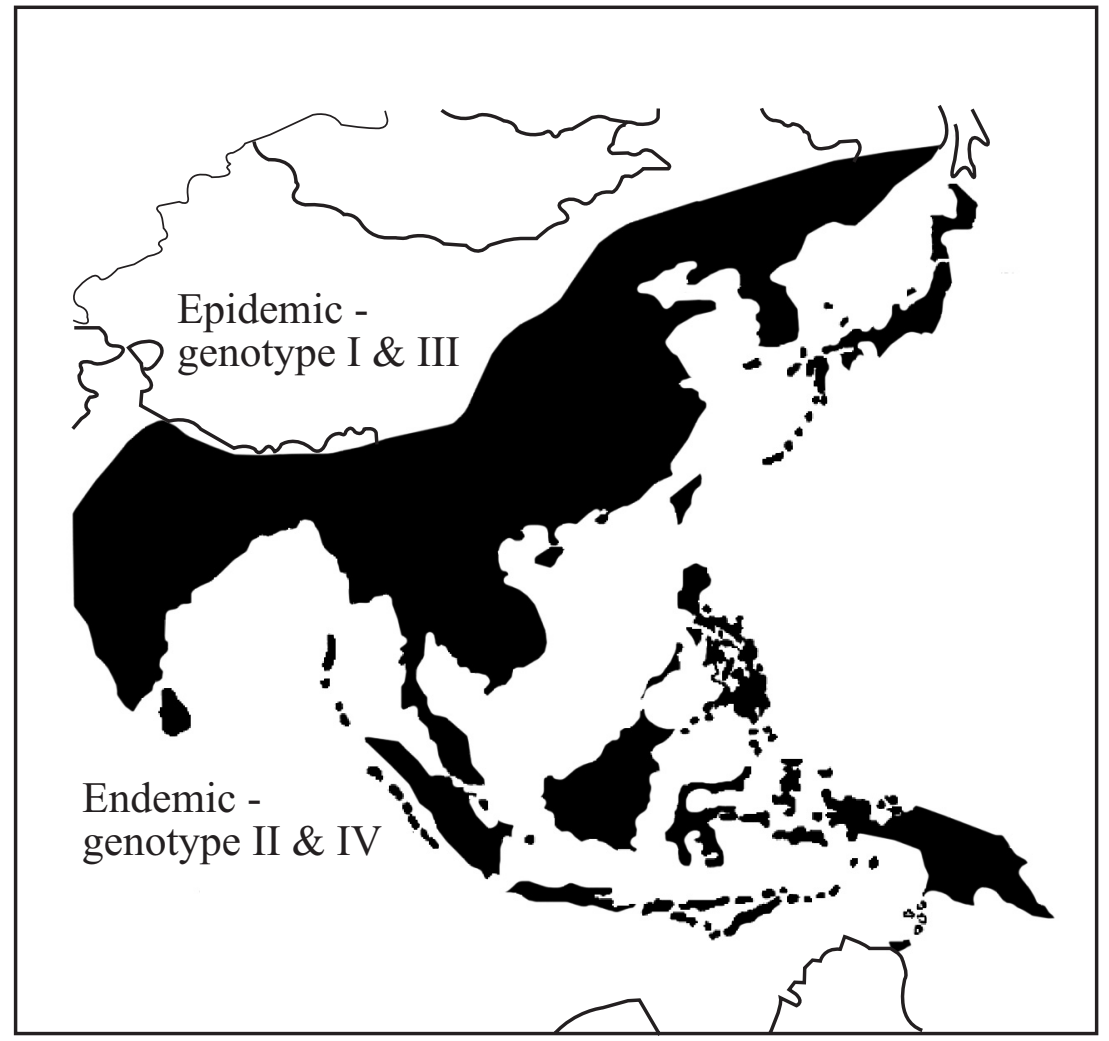

Map 1. The distribution of Japanese encephalitis in the South Asia and Asia pacific region reproduced from: Solomon, T.; Winter, P.M. Arch. Virol. Suppl., 2004, 161-70. 


\section{Epidemiological Trends}

There are 4 main genotypes (labelled 1-4) spread over Asia and Australasia (see map 1). Genotype 1 and 3 are associated with the epidemic form (in the more temperate Asian regions) and 2 and 4 associated the endemic form (in the more tropical Asian regions). Genotype 3, which includes the Beijing, Nakayama and SA14 strains, is the most widespread [18].

An important aspect of disease trends in the last 30 years has been decline in the incidence of JE in some regions accompanied by spread and outbreaks of JE into other areas. Japan, South Korea, Taiwan, have virtually eliminated JE while Thailand and the People's Republic of China (China) have seen significant declines in disease incidence (see Fig. 1 and 2) $[2,11,12]$. However, the disease has now spread into Nepal, Papua New Guinea, Torres straits, Cape York, Pakistan and previously non-endemic parts of India [1,19-22]. In Nepal, the disease was first recorded in 1978 in Rupandehi district. From then 26,667 cases and 5,381 deaths have been recorded by 2005 [20]. Recent outbreaks have also been reported in Nepal and India (Uttar Pradesh and Bihar with nearly 5000 cases and 1300 deaths). There have been regular outbreaks in the Indian states of Andhra Pradesh, West Bengal, and Tamil Nadu, and in Sri Lanka, and JE is now considered endemic in these areas $[1,18,23]$. Vietnam still reports periodic outbreaks while Bangladesh, Bhutan, Indonesia, Myanmar, Timor, Cambodia, Brunei, Laos, Malaysia and Philippines remain endemic, with small or anecdotal reports or no clear data [1].

In Kurnool district India, JE incidence dropped $77 \%$ from $369 / 100000$ people before immunization to $84 / 100000$ three years later [1]. In China increased vaccine usage in the 1980 s also preceded a drop in the incidence of JE, from 10$20 / 100000$ in the 1960's and 70's to 2.5/100 000 in 1990 and $0.5 / 100000$ in 2004 [1,24]. Chinese government support of a low fee for JE immunisation was thought to have contributed to a $90 \%$ reduction in incidence [24]. Greater declines over two decades were seen in 4 provinces where the vaccine was free and delivered through the EPI network compared to another 4 provinces where it was not free and not offered in the EPI (rate of reduction $96.2 \%$ versus $78.8 \%$ ) [24]. JE outbreaks still occur in China and it remains a public health concern with 5104 cases and 214 deaths reported in 2005 [25]. Taiwan saw a dramatic drop with a peak

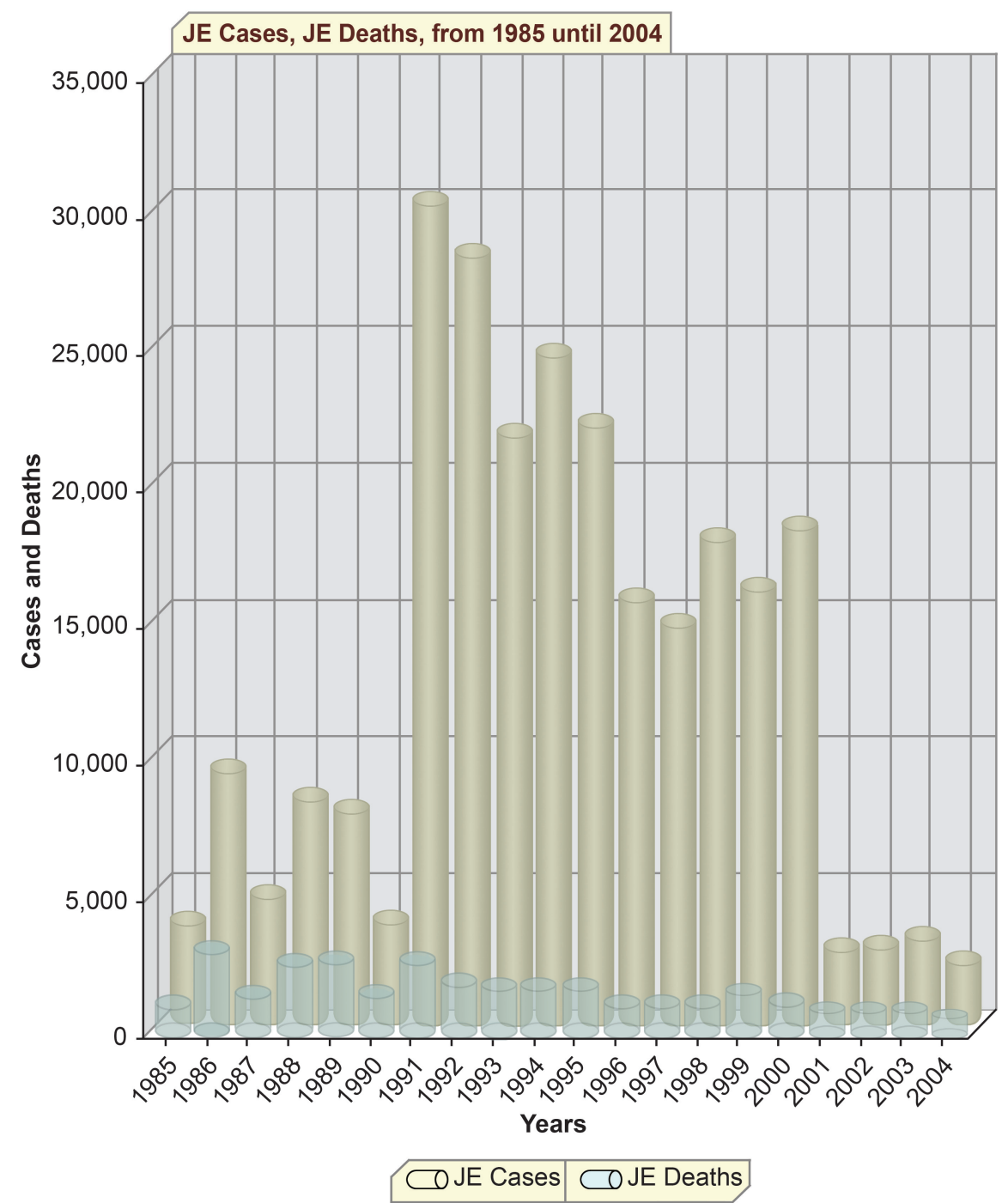

Fig. (1). Number of JE cases and deaths reported, 1985-2004 reproduced from Japanese encephalitis prevention network (JEPN), interactive chart display, copyright 2005 PATH. https://jepn.org/jepn/RegionChart1.aspx 


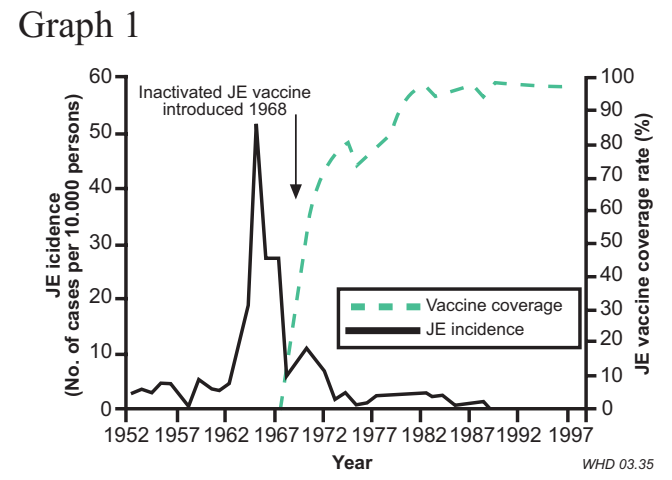

Graph 3

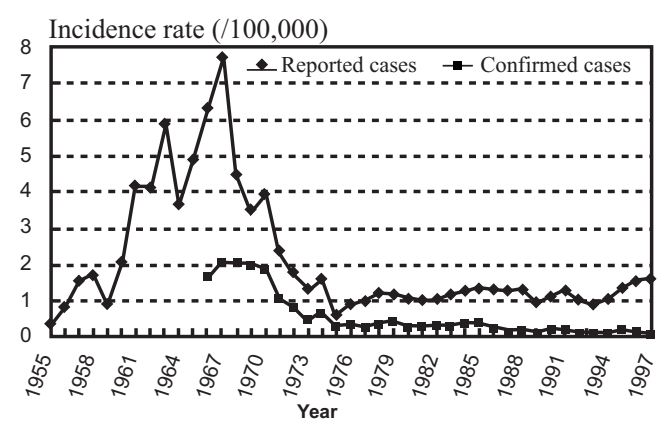

Graph 2

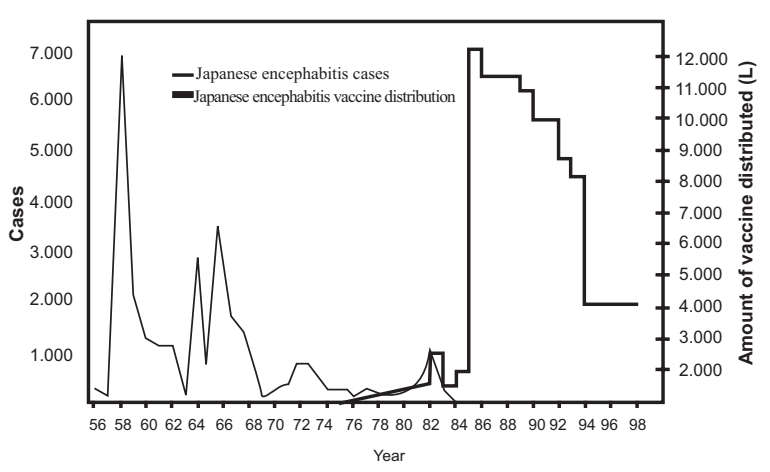

Graph 4

Annual number of JE cases in Japan 1948-1998

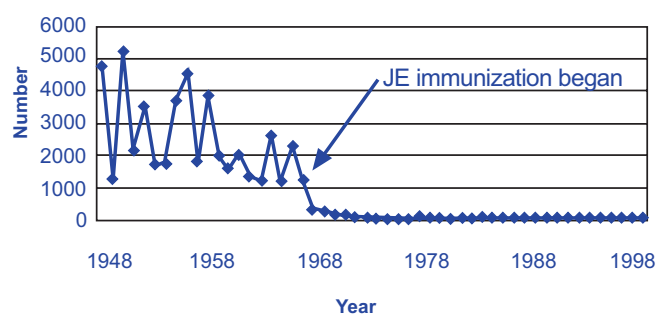

Fig. (2). Declining trend in the incidence of Japanese encephalitis cases in 4 countries

Graph 1: Incidence of JE and vaccine coverage of 1 year olds with two dose primary series of the P3 strain vaccine, Shanghai, China, 195298. Reproduced from: Ding, D.; et al. Bull World Health Organ., 2003, 81, 334-42.

Graph 2: Cases of JE according to litres of vaccine distributed, 1936-98, South Korea. Reproduced from: Sohn, Y.M. Emerging Infectious Diseases, 2000, 6, 17-24.

Graph 3: Incidence of reported and confirmed (hemgglutination inhibition test) cases of JE in Taiwan 1955-97. Note that vaccination was introduced in 1968. Reproduced from: Wu, Y.C.; et al. Am J Trop Med Hyg, 1999, 61, 78-84.

Graph 4: Decline of cases in JE in Japan, 1948-1998. Reproduced from PATH website 'Japanese encephalitis in depth', http://www.path.org/projects/JE_in_depth.php

of 2.05/100 000 confirmed cases in 1967 (the year before vaccination was introduced) to $0.03 / 100000$ confirmed cases in 1997 (see Fig. 2, Graph 3) [12]. Other interesting trends in countries with established vaccination programmes have been an increase in the age of reported cases [12]. By the 1990's two thirds of Korean cases were middle aged adults [11]. Similar trends were seen in mainland China, Taiwan and in Japan where recent outbreaks have been in older age groups $[12,21,26,27]$.

While data does strongly suggest that vaccination has led to a fall in incidence, other factors such as improved living conditions, shrinkage of rice fields and centralisation of the pig industry that have occurred through the economic boom of the Asian economies may be important (see Fig. 2, Graphs 1-4) [12]. Indeed, incidence rates in unvaccinated infants in Taiwan dropped from 6.4/100 000 in 1966 to $0.35 / 100000$ in 1980 [12]. The experience in South Korea had shown falling incidence some years prior to introduction of vaccination (Fig. 2, Graph 2), and widespread use of herbicides and insecticides, removal of mosquito habitats and decline in vector density have been cited as contributing factors [11]. In contrast, increased rice flooding and changing animal husbandry has also occurred. While Japan and South Korea have reduced rice acreage, most Asian countries have increased it by $20 \%$. Together this may explain the changing epidemiology of JE and increased relative importance of the disease in countries such as India and Nepal [28].

\section{CURRENT VACCINES}

\section{Mouse Brain Derived Inactivated (MBDI)}

MBDI was developed in the 1930s, and a purified version of this vaccine became available in 1966. The vaccine is derived from infected mouse brain tissue suspensions that are inactivated by formalin and purified through several steps. Purification aims to reduce impurities such as myelin basic protein (to <2ng/ml) [29]. However, this, together with the stabiliser gelatin have raised concerns about being linked with adverse events [30].

There are currently two types of vaccines; one from brain tissue infected with the Nakayama strain, and the other with 
a Beijing strain. The vaccine comes as a 10 or single dose, either liquid or freeze-dried (reconstituted with water), is stored at temperatures from $2^{\circ}-8^{\circ} \mathrm{c}$ which preserves stability for 1 year and is administered subcutaneously [3]. The vaccine is costly and is difficult to produce to economies of scale, though is widely licensed and is manufactured in numerous countries. The vaccine is widely used in Asian countries including South Korea, Japan, Thailand, Vietnam, Sri Lanka and Malaysia as well as numerous other countries where its is prescribed for travellers going to at risk areas [1]. With additional costs including cold chain, dilutent for reconstitution and transport, large scale production to meet local needs remains a challenge [9]. There have been numerous studies looking at the safety and efficacy of the MBDI vaccine. Clinical studies done over the last 25 years have been summarised in Table $\mathbf{1}$ and $\mathbf{2}$ [12,31-55].

\section{Vaccine Efficacy}

A large randomised double blind study in Thailand showed an efficacy of $91 \%$ (95\% CI, 70-97\%) after 2 doses of MBDI vaccine compared to placebo (tetanus toxoid), with few adverse and no severe adverse events [52]. The study

Table 1. Efficacy or Effectiveness of the MBDI Vaccine (Last 25 Year)

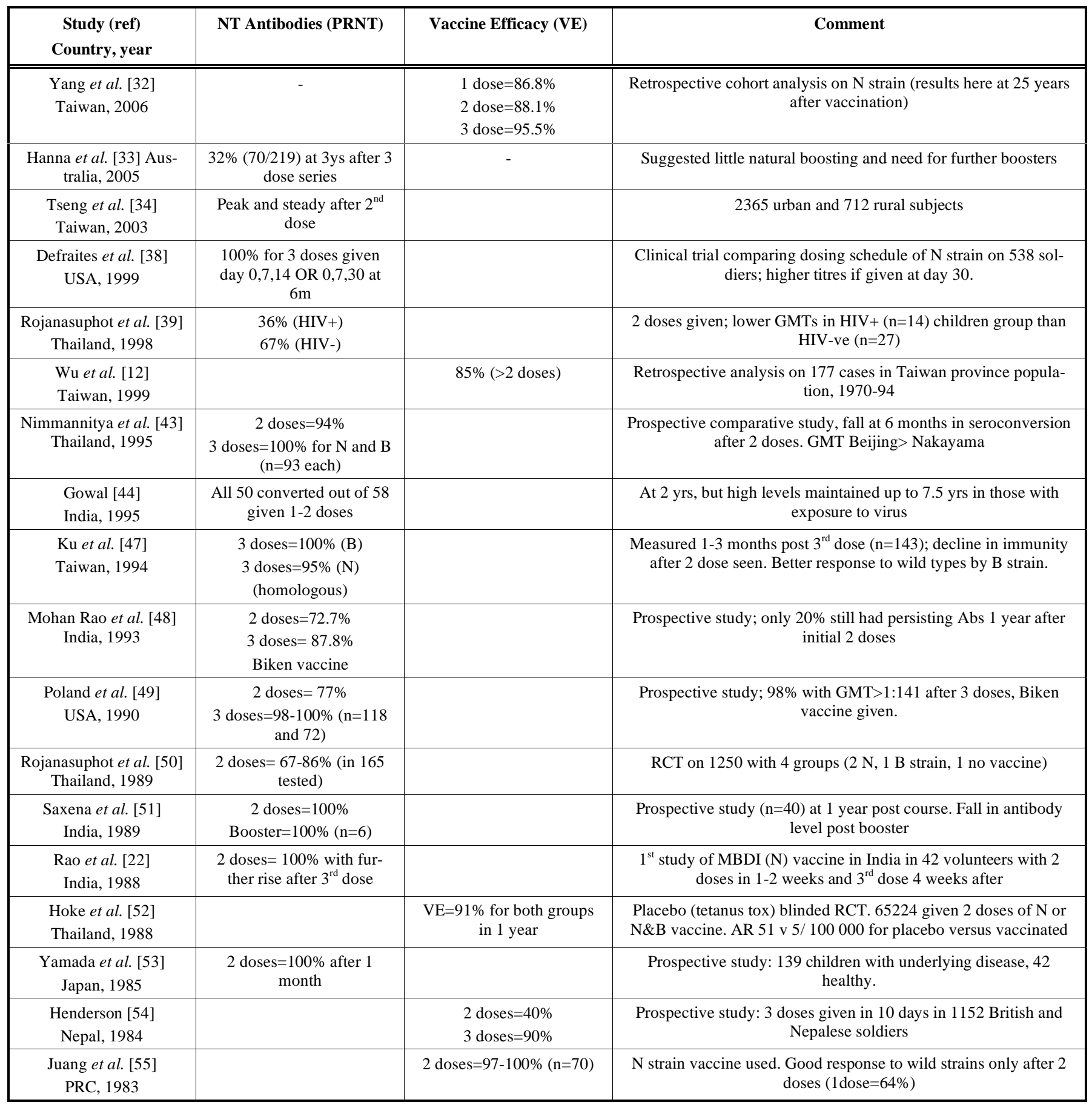


Table 2. Safety of the MBDI Vaccine (Last 25 Year)

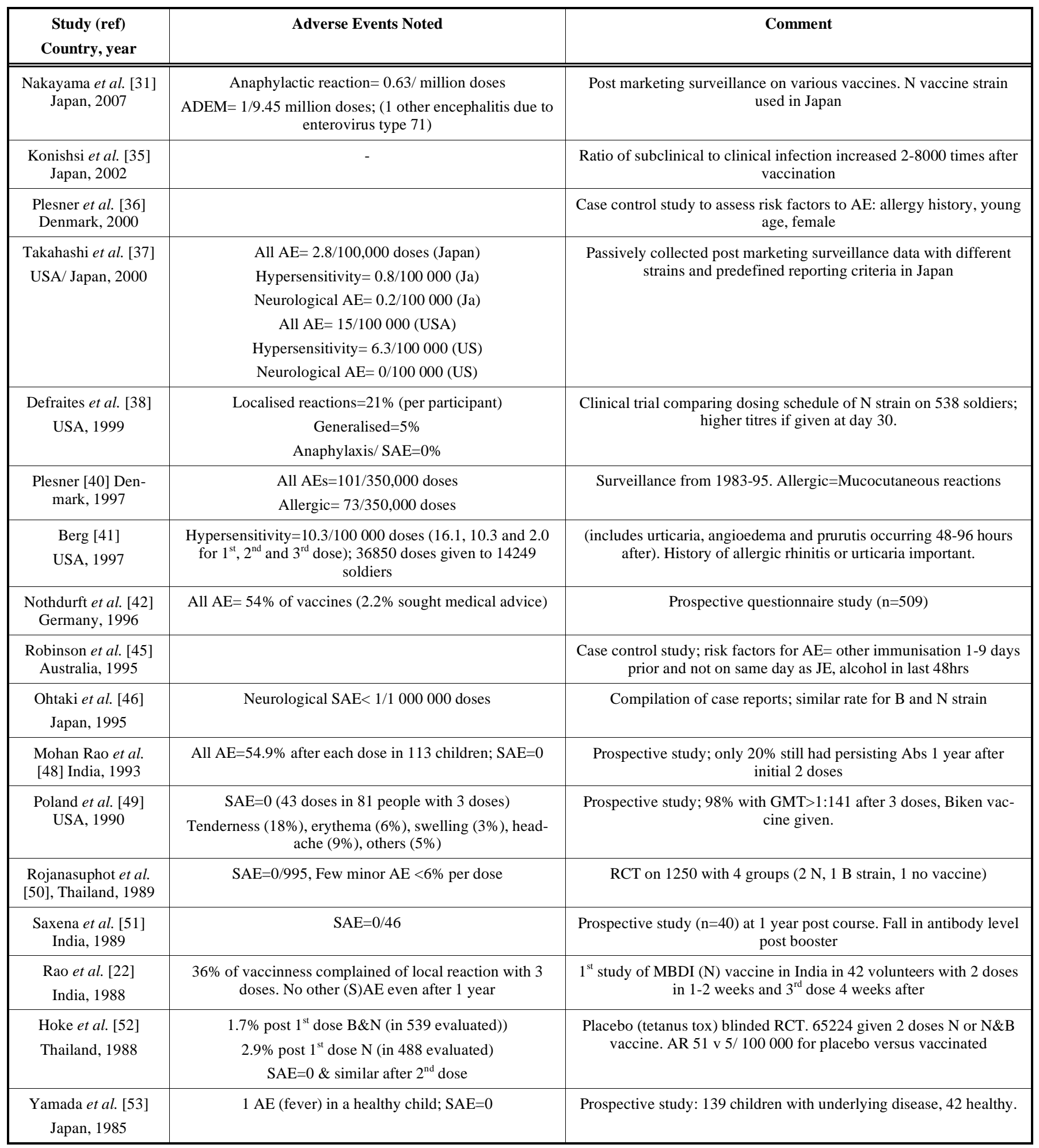

$\mathrm{S}(\mathrm{AE})=$ serious (adverse event); $\mathrm{B}=$ Beijing strain; $\mathrm{N}=$ Nakayama strain.

also showed some possible protection to dengue fever. The study paved the way for licensure of the Nakayama vaccine by the U.S FDA [29]. An earlier study in a smaller sample of participants had also showed good neutralising (NT) antibody response to two doses [55]. However, numerous other studies have shown that 2 doses are probably insufficient to provide adequate protection [43,48-50]. A study in the U.S.A in a non immune population with non continual exposure had an NT antibody response of only $77 \%$ after 2 doses, increasing to $>98 \%$ after the third dose (no 95\% CI given) [49]. A more recent Australian study also showed that response after 3 years to 3 doses fell as low as $32 \%$, suggesting again that natural boosting possibly plays an important part in maintaining high NT levels [33]. In contrast, a retrospec- 
tive analysis from Taiwan showed that even after 25 years, vaccine efficacy was as high as $88 \%$ after 2 and $95 \%$ with 3 doses (no 95\% CI given) [32]. The authors raised the question whether the 'cut off' titres of PRNT to define protection needs to be reconsidered. However studies from Thailand and India show that the 3 dose schedule is reasonable to provide good protection $[43,48]$. The vaccine is therefore given as an initial 3 dose series for children from $12+$ months, with two doses 1 to 4 weeks apart followed by a third 1 year later. Schedule of booster doses of MBDI vary between countries. For travellers from non-endemic countries the three dose regimen is shortened to days 0,7 and either 14 or 30 [29]. A study in the US showed that both these regimens have good immune responses, with higher titres for the 30 days regimen [38]. Hence travellers with shorter deadlines can still benefit from the 2 week regimen.

The study by Hoke et al. showed little difference in protection between the 2 main vaccine strains; the Nakayama strain and Beijing/ Nakayama bivalent vaccine had $91 \%$ efficacy [52]. However the Beijing vaccine seems to have broader antibody response to wild type strains and has a higher potency $[43,47]$. Thus the Beijing strain is given at half the volume dose of the Nakayama strain $(0.5$ and $0.25 \mathrm{ml}$ versus $1 \mathrm{ml}$ and $0.5 \mathrm{ml}$ for children $>3$ years and $1-3$ years respectively). This reduction in quantity of vaccine per dose would increase the production capacity of the Nakayama strain based vaccine.

\section{Adverse Events and Toxicity}

The concern of adverse events (AEs) remains a big barrier for increasing the coverage of the MBDI vaccine. Allergic/ hypersensitivity and neurological reactions are the main types of AEs. Reactions can be localised or systemic and vary from mild to severe. Hypersensitivity reactions tend to be delayed up to 48 hours post vaccination, which can be longer with successive doses [29]. Two types have been noted- cutaneous /respiratory (urticaria and wheezing) and cardiovascular (hypotension), with the former being linked with gelatin $[3,30,56]$. Severe neurological reactions following MBDI vaccination have been well accounted. A case series in Denmark reported 10 neurological cases occurring within a few weeks of vaccination with 3 cases described as acute disseminated encephalomyelitis (ADEM), though a causal link has not been confirmed. Symptoms and signs of these 10 cases ranged from headaches, difficulty in concentrating, paraesthesia, parkinsonian gait, and myelitis [57]. Risk factors for hypersensitivity include history of allergy (including asthma, hayfever, rhinitis, nickel sensitivity), young age, female sex $[36,41]$. Other risk factors for adverse events could include alcohol consumption in the 9 days prior to (but not on the day of) JE vaccination [45].

Rates of such AEs vary depending on surveillance criteria and existence of good data collection systems. Table $\mathbf{2}$ demonstrates differences in some of the reported studies. The rate of post vaccination $\mathrm{AE}$ observed by the postmarketing surveillance in Japan (national adverse reaction reporting system) differed from that by the vaccine adverse event reporting system in the USA. The rate of hypersensitivity was 10 fold higher $(6.6$ versus $0.8 / 100000)$ and all adverse events were 5 fold higher in the USA than in Japan. In Japan the neurological events were 0.2/100 000 and there was none in the USA. This variation in the rate of AEs may due to differences in number doses of vaccine given (9.4 million in Japan in 26 months versus 813,000 doses in USA in 5 years) but it can well be due to methodological differences between the two systems [37]. Higher rates of AEs were found in Denmark; the rate of allergic mucocutaneous reactions was 73/350,000 doses and rate of any AEs was $101 / 350,000$ doses) [40]. Other studies have found that while local, mild reactions are common, low rates of serious adverse events occur, though few have had sufficient sample sizes and follow up times to detect rare neurological events $[31,38,41,42,46,48-53]$. Overall rates of local reactions has been estimated around $20 \%$, mild systemic at $10-30 \%$, hypersensitivity at 1-64/10 000 and acute encephalitis at 1/75 000 to $1 /$ million doses [1]. In May 2005, following concerns of serious adverse events (SAEs), Japan suspended routine vaccination with the MBDI vaccine and this has vaccination policy implications for other countries with very low incidence of JE [58].

\section{Live Attenuated SA 14-14-2}

An important milestone in JE vaccines occurred with the development of the only available live attenuated SA 14-142 vaccine by $\mathrm{Yu}$ Yong Xin and collegues. The vaccine was derived from a wild type SA 14 virus strain recovered from a Culex pipiens mosquito larvae in 1954 [29]. The vaccine is now produced in Primary Hamster Kidney (PHK) cell cultures infected with the seed virus [3]. Importantly, the virus was licensed in China in 1989 and since then has replaced the older P3 strain PHK vaccine for routine use in immunisation [29]. The vaccine is produced locally by several Chinese companies and for export use by the state owned Chengdu institute of biological products (CDIBP). This vaccine is available as a 5 dose or single vial lyophilised powder (with reconstituent solution) and stored between $2^{\circ}-8^{\circ} \mathrm{c}$. Dose regimen is $0.5 \mathrm{ml}$ subcutaneously and has been given to children as young as 6 months. A booster dose has been given in China but is not considered as essential [24].

According to a drug fact sheet made in collaboration with PATH, important steps are taken to ensure the quality and safety of the vaccine [59]. The master virus seed has been screened and shown to be free of adventitious virus by QOne Biotech, UK. The PHK cell line used to prepare the virus has also been screened and declared pathogen free. Finally the CDIBP quality assures all vaccine lots by further testing for adventitious agents and it is manufactured according to guidelines developed by a WHO expert committee on biological standarisation $[59,60]$. The issue of quality is important as the unprecedented use of PHK cell for vaccine production with its source from live animals has raised concerns over primary cell production and adventitious infectious agents being in the initial tissue or introduced later [3]. This has led to a lack of international approval. Hence in 2002 , the WHO developed the guidelines for production and control of live attenuated JE vaccines with the SA 14-14-2 vaccine in mind $[29,59,60]$. So far the vaccine has remained attenuated in animal studies and viraemia induced by vaccination is likely to be below threshold for infection to mosquitos [29]. Furthermore, the vaccine has a good safety and efficacy record in clinical studies (Table 3) [13,61-71].

\section{Vaccine Efficacy}

The efficacy of this vaccine has been demonstrated in Nepal and South Korea. A case control study in China by 
Table 3. Safety and Efficacy/Effectiveness of the Live Attenuated SA 14-14-2 Vaccine Last 25 Years)

\begin{tabular}{|c|c|c|c|c|c|}
\hline $\begin{array}{l}\text { Study (ref), } \\
\text { Country, year }\end{array}$ & Adverse Events Noted & $\begin{array}{l}\text { Vaccination } \\
\text { Challenge Test }\end{array}$ & $\begin{array}{l}\text { NT Antibodies } \\
\text { (PRNT) }\end{array}$ & $\begin{array}{l}\text { Vaccine Efficacy } \\
\text { (VE) }\end{array}$ & Comment \\
\hline $\begin{array}{l}\text { Weekly epi } \\
\text { record [61] } \\
\text { India, } 2007\end{array}$ & $\mathrm{SAE}=65 / 9.3$ million vaccinee children & - & - & - & $\begin{array}{l}\text { Surveillance data } \\
\text { Most thought unre- } \\
\text { lated to vaccine }\end{array}$ \\
\hline $\begin{array}{l}\text { Tandan et al. } \\
\text { [62] Nepal, } \\
2007\end{array}$ & - & - & - & $\begin{array}{l}96.2 \% \text { (at five yrs) to } \\
\text { single dose }\end{array}$ & $\begin{array}{l}20 \text { cases, } 219 \text { con- } \\
\text { trols(continuation of } \\
\text { below study) }\end{array}$ \\
\hline $\begin{array}{l}\text { Bista } \text { et al. }[64] \\
\text { Nepal, } 2001\end{array}$ & - & - & - & $\begin{array}{l}99.3 \% \text { (at } 2 \mathrm{~m} \text { ) to } \\
\text { single dose }\end{array}$ & $\begin{array}{l}\text { Age-sex matched } \\
\text { case control study, } 20 \\
\text { cases, } 557 \text { controls }\end{array}$ \\
\hline $\begin{array}{l}\text { Sohn et al. }[66] \\
\text { South Korea, } \\
1999\end{array}$ & $\begin{array}{c}\text { SAE }=0 / 86 \text { vaccinees } \\
\text { Mild AE }=11 \%(10 / 86) \text { : Fever } 7 \%, \\
\text { Vomiting } 1 \% \text {, Rash } 1 \% \text {, irritability } 1 \% \text {, } \\
\text { Loss appetite } 1 \%\end{array}$ & - & $\begin{array}{l}96 \%(\text { GMT } 188 \\
\text { after single dose in } \\
\quad 68 \text { children })\end{array}$ & - & Prospective study \\
\hline $\begin{array}{l}\text { Zhou et al. }\{\text { iii }\} \\
\text { China, } 1999\end{array}$ & $\begin{array}{c}\mathrm{AE} \text { or } \mathrm{SAE}=0 \text { noted in } 335,941 \mathrm{vac}- \\
\text { cinee children }\end{array}$ & - & $83.9-94.7 \%$ & - & $\begin{array}{l}\text { Surveillance data } \\
\text { Significantly reduced } \\
\text { mortality and inci- } \\
\text { dence }\end{array}$ \\
\hline $\begin{array}{l}\text { Guo et al. }\{\mathrm{i}\} \\
\text { China, } 1998\end{array}$ & & & $\begin{array}{c}1 \text { dose }=56 \% \\
2 \text { dose }=95 \%(6 \mathrm{~m})\end{array}$ & & $\begin{array}{l}\text { Comparative study } \\
(\mathrm{n}=319) \text { with inacti- } \\
\text { vated vacc. }\end{array}$ \\
\hline $\begin{array}{l}\text { Liu et al. [68] } \\
\text { China, } 1997\end{array}$ & $\begin{array}{c}30 \text { days short term follow up } \\
\text { Encephalitis } / \text { meningitis }=0 \\
\text { RR hospitalisation }=0.7(0.43-1.15) \\
\text { RR for seizures }=0.91(0.37-2.22) \\
\text { Fever }=0.79(0.56-1.11)\end{array}$ & - & - & - & $\begin{array}{l}\text { Randomised con- } \\
\text { trolled study with } \\
26,239 \text { subjects } \\
(13,266 \text { vaccinated })\end{array}$ \\
\hline $\begin{array}{l}\text { Hennessy et al. } \\
\text { [69] } \\
\text { China, } 1996\end{array}$ & - & - & - & $\begin{array}{l}80 \% \text { one dose } \\
97.5 \% \text { two doses }(1 \\
\text { yr apart })\end{array}$ & $\begin{array}{c}\text { Village and age } \\
\text { matched case control } \\
\text { study ( } 56 \text { cases, } 1299 \\
\text { controls) }\end{array}$ \\
\hline $\begin{array}{l}\text { Ma et al. }[70] \\
\text { China, } 1993\end{array}$ & $\begin{array}{l}\text { SAEs }=0 / 867 \text { children actively fol- } \\
\text { lowed (only few minor AEs noted) }\end{array}$ & & & & $\begin{array}{l}588512 \text { children } \\
\text { given } 4 \text { doses }\end{array}$ \\
\hline $\begin{array}{l}\text { From Halstead } \\
\text { \& Tsai, Plotkin } \\
\text { [13] } \\
\text { China }\end{array}$ & - & - & - & $\begin{array}{l}95 \%-100 \% \text { (inci- } \\
\text { dence compared in } \\
541,461 \text { vaccinated } \\
\text { versus } 95,618 \text { unvac- } \\
\text { cinated) }\end{array}$ & $\begin{array}{l}7 \text { reports in } 4 \text { Chi- } \\
\text { nese provinces from } \\
1988-93\end{array}$ \\
\hline $\begin{array}{l}\text { From Halstead } \\
\& \text { Tsai, Plotkin } \\
\text { [13] China }\end{array}$ & & & $\begin{array}{l}\text { Range of } 71-100 \% \\
\text { (171 out of } 194 \text { or } \\
88 \% \text { altogether) }\end{array}$ & & $\begin{array}{l}5 \text { prospective studies } \\
\text { with } 1 \text { dose, from } \\
1979-1994\end{array}$ \\
\hline $\begin{array}{l}\text { Xin et al. }[71] \\
\text { China, } 1988\end{array}$ & $\begin{array}{l}\text { Fever, systemic reactions or } \mathrm{SAE}=0 / 47 \\
\text { vaccinees } \\
\text { No AEs reported in } 1,026 \text { vaccinnees }\end{array}$ & - & $\begin{array}{l}100 \% \text { in small } \\
\text { selected group } \\
\quad(\mathrm{n}=23)\end{array}$ & - & $\begin{array}{l}83 \% \text { sero-coversion } \\
\text { in } 12 \text { children with } \\
1: 50 \text { dilution }\end{array}$ \\
\hline
\end{tabular}

For case control studies $\mathrm{VE}=1-\mathrm{OR}$ used as approximate for risk ratio; $\mathrm{AR}=$ attack rate; $\mathrm{S}(\mathrm{AE})=$ serious (adverse event); $\mathrm{B}=\mathrm{Beijing}$ strain; $\mathrm{N}=\mathrm{Nakayama}$ strain; \{\}$=$ see footnotes in text. 
Hennessy et al. showed that vaccine efficacy improved after a second dose a year later from $80 \%(95 \% \mathrm{CI}, 44-93 \%)$ to $97.5 \%$ (95\% CI, 86-99.6\%). Low seroconversion rates after one dose were also seen by Guo et al. which improved after a second dose from $56 \%$ to $95 \%$ (95\% CI not reported in the abstract in English) $)^{1}$. In an attempt to make a more compatible schedule to the EPI, Tsai et al. showed good seroconversion ranging from 94-100\% (95\% CI not reported) with a second dose given just 1 or 2.5 months after the first dose [67]. However a recent case-control study with a five year follow up of an area vaccinated solely with the live JE vaccine in 1999 showed maintenance of good vaccine efficacy$99.3 \%$ up to 2 months (95\% CI, 94.9-100\%), $98.5 \%$ (95\% CI, 90.1-99.2\%) up to 15 months and $96.2 \%$ (95\% CI, 73.1$99.9 \%$ ) up to 5 years post vaccination [62-4]. This agrees with observations in Thailand and in China (of up to 11 years) showing protection after a single dose. At the very least the one dose regimen allows rapid vaccination in areas without routine $\mathrm{JE}$ vaccination or prone to outbreaks. Using live attenuated vaccine as a booster following inactivated vaccine showed a NT antibody response of $97.7 \%$ (95\% CI not reported in the English abstract) in a study in China ${ }^{2}$.

\section{Adverse Events and Toxicity}

Open label data from $1988-93$ on over 600,000 children in China indicate low rate of adverse events (fever $<5 / 10,000)$ and vaccine efficacy around $98 \%$, confirming earlier data that showed no adverse events in 1,026 vaccinated children [29,71]. Since then rigorous studies have shown good safety. A large randomised controlled trial in China with 26,239 subjects (13,266 vaccinated children) showed similar relative risk of adverse events (hospitalisation, seizures, fever) in the vaccinated and unvaccinated groups after 30 days follow up and no severe adverse or neurological events were observed [68]. Two further studies including one in South Korea have shown no severe adverse events and a low rate of mild events- fever, rash, irritability loss of appetite in around $10 \%[66]^{3}$. The most recent experience with surveillance following large scale vaccination in India showed a low rate of SAEs, with most considered unrelated to vaccination and due to background morbidity and mortality [61].

The live JE vaccine has been co-administered safely with measles vaccine in a study in the Philippines to 9 month-old children and it showed good co-retention of immunogenicity $^{4}$. It also has been shown to provide protection against wild type strains of the JE virus [65].

Good safety and efficacy have made the SA 14-14-2 vaccine an attractive option prompting Boran pharmaceutical, a South Korean company to obtain the right to distribute the vaccine. It has now been licensed and used in South Korea

\footnotetext{
${ }^{1}$ Guo, W.; Li, L.; Wu, Z. Zhonghau Liu Xing Bing Xue Za Zhi, 1998, 19, 97-9. [Article in Chinese with English abstract].

${ }^{2}$ Ma, F.B.; Zheng, L.; Bi, C. Zhonghau Liu Xing Bing Xue Za Zhi, 2003, 24, 113-5. [Article in Chinese with English abstract].

${ }^{3}$ Zhou, B.; Jia, L.; Xu, X. Zhonghau Liu Xing Bing Xue Za Zhi, 1999, 20, 38-41. [Article in Chinese with English abstract].

${ }^{4}$ Gatachalian, S.; Yao, Y.; Zhou, B.; et al. Measles vaccine immunogenicity after coadministration with live Japanese encephalitis vaccine shows equivalence to that of the measles vaccine given alone (abstract), Proceedings of the American Society of Tropical Medicine and Hygiene $54^{\text {th }}$ Annual Meeting., Atlanta (GA), USA, Nov 12$16^{\text {th }}, 2006$.
}

(2001), Nepal (1999), and India (2006) [59]. India is already planning to further scale up use of the vaccine and has planned to purchase 21.3 million doses [72]. The vaccine has also been licensed in Sri Lanka. The manufacturer is currently preparing a dossier for WHO pre-qualification enabling procurement for UN agencies though this is not a prerequisite for national licensing, and growing use of the vaccine continues with a maximum set public sector price for lower income countries.

\section{Cell Culture Derived Inactivated (P3 Strain)}

This vaccine is a formalin inactivated virus from supernatant material derived from PHK cells infected with the Beijing P3 strain [8]. The vaccine has only been manufactured and administered in China since 1968 where it was used as the principal vaccine of choice. Over 70 million doses were given to children under 10 years of age between 1968-1994 [73]. Trials of this vaccine in China from 196773 showed similar effectiveness as the MBDI vaccine. Two doses of $0.25 \mathrm{ml}$ were given subcutaneously (1 week apart) from the age of 6-12 months, with 2 repeat doses of $0.5 \mathrm{ml}$ between 1-7 years and 2 further doses of $0.5 \mathrm{ml}$ after 7 years; as immunity was seen to rapidly wane after the first two doses [3,73]. An age and sex matched case-control study with an accompanying surveillance system and laboratory confirmation to detect cases conducted in Henan province in 1991 showed a vaccine efficacy of $78 \%$ (95\% CI, 16-94\%) for those fully immunised and around 68\% (95\% CI, 0-92\%) for those partially immunised [73]. The vaccine was widely used as it was cheap and no encephalitic adverse events had been noted [8]. Mild adverse events were $<5 \%$ and the rate of hypersensitivity was $1 / 15000$ vaccinated subjects [8]. This vaccine has, however, not been widely used and studied outside China, where it is now being superseded by the live attenuated SA 14-14-2 vaccine.

\section{Cost and Cost-Effectiveness of Current Vaccines}

The cost of the three vaccines in use varies. The P3 and live attenuated vaccines are cheap and total (including associated factors like storage, salaries, transport, supplies etc) cost per dose is around US\$0.60 in China [74]. The live attenuated SA 14-1-4-2 vaccine has also had a maximum public sector import price (outside China) established for state health systems of low-income countries with GDPs <US\$1000 per capita [75]. This has been set to be comparable to the cost of the measles vaccine. As the MBDI vaccine is produced in many countries, prices can vary, though some Asian countries can afford to pay as much as US\$4.50 per dose [75].

There have been few cost-effectiveness analyses in the past. A decision analysis model study from Thailand published 10 years ago looked at the feasibility of inclusion of the MBDI vaccine into the routine EPI program for children at either 18 months (costing US\$2.16 per person) or 6 years of age (costing US\$3.68 per person). The study found that vaccinating at 18 months of age had a better cost effectiveness ratio than at 6 years (US\$ $15,715 \mathrm{v} \$ 21,661$ ) with benefits made in preventing treatment cost, disability care and future earnings loss [76]. The study concluded that the JE vaccination programme was worth implementing when incidence was > 3/100 000. A later study in Shanghai using another decision-analytical model with disability adjusted life 
years (DALYS) and a longer 30 year follow up compared 3 cohorts with either no vaccination, P3 inactivated and the live attenuated SA 14-14-2 vaccine [74]. Both routine vaccination strategies were found to be cost saving. The live vaccine had better cost saving than the P3 vaccine (DALYS prevented 6556 versus 6456; net cost savings US\$512,456 versus US\$348,246). A third of savings was due to prevention of long-term disability. This analysis also found that cost savings for the live vaccine was maintained up to an incidence of $6.1 / 100000$ at a cost per dose of $\$ 3.30$. A study in India compared the live and MBDI vaccine as either mass campaign or routine vaccination programmes in 18 districts in Andhra Pradesh [77]. Immunization with the live SA-1414-2 vaccine was shown to be more cost effective, costing US\$58 per DALY prevented for a one-time campaign and US\$78 per DALY prevented for a one time campaign combined with a 5-year routine immunisation programme. Finally, another decision model analysis done by the International Vaccine institute in Thailand, Vietnam and China on cohorts followed up from neonate to 30 years of age with the inactivated and live vaccine (China only) found that JE vaccination was cost effective and indeed was cost saving in China where the live SA 14-14-2 vaccine was used [1]. The studies have limitations particularly in the ability to conduct only a one-way sensitivity analysis. Nonetheless, JE vaccination, particularly with the live attenuated SA 14-14-2 vaccine is seen to be a cost-effective and worthwhile intervention.

\section{FUTURE PERSPECTIVES FOR VACCINES}

There have been several developments into potential new vaccines for JE. These have included work into Poxvirus based vaccines (interest in which has diminished due to limited success), DNA vaccines, Chimeric viral vaccines and use of Vero cells to develop inactivated vaccines of established strains. A comprehensive review of these new developments is beyond the scope of this paper and only promising vaccines in clinical development are considered herenamely Chimeric and Vero cell line vaccines. The US food and drug administration (FDA) and European agency for the evaluation of medicinal products (EMEA) licensure and prequalification of these vaccines is possible in the next few years.

Chimeric Live Attenuated Vaccine: is a recombinant vaccine developed by Acambis that uses the established and safe 17D yellow fever vaccine strain as a 'backbone' genome in which antigen coding sequences of the SA 14-14-2 strain is inserted into. This is then cultivated on the established Vero cell line. Initial animal studies on mice and primates that inserted the pre-membrane and envelop (prME) coding genes of the SA 14-14-2 strain into the established YF 17D vaccine virus showed genetic stability after sequential passages in cell lines, no neuro-virulence, and no detectable JE viraemia post-challenge following a single subcutaneous dose [78.79]. Clinical proof of principal was established when the vaccine was shown to produce a $100 \%$ seroconversion rate $(n=24)$ in YF naïve and immune subjects following one dose and with no serious adverse events [80]. A later double blind phase 2 trial showed that 86 of 87 subjects developed NT antibodies ( $\mathrm{PRNT}_{50}$ assay) to the vaccine with no significant booster effect with a second dose and a lower response seen to wild type strains. The vaccine was well tolerated with no SAEs [81]. The 'ChimeriVax' is undergo- ing phase 3 clinical trials in Australia, United States and India (paediatric studies) and Acambis has entered partnership with Bharat Biotech International limited to market and distribute the vaccine in India and the region after licensing [75]. The vaccine requires a cold chain, but cost is expected to be low [3].

Inactivated Attenuated Derived SA 14-14-2 Strain, Vero Cell Derived Vaccine (IC51): is being developed by Intercell and Walter Reed Army institute of research (WRAIR). Work on the feasibility of using the attenuated SA 14-14-2 strain in Vero cells was published in China in $1999^{5}$. Studies on mice done by the WRAIR showed the vaccine to be highly immunogenic and safe [82]. A subsequent phase 2 study involving 94 volunteers given either the MBDI or the 'purified inactivated SA 14-14-2 vaccine' (PIV) showed no SAEs, few milds AEs and good seroconversion rates of between $95-100 \%$ with 2-3 IM doses of $12-24 \mathrm{mcg}$ $(n=73)$ of the JE-PIV as compared to $74 \%(n=21)$ for the licensed JE vax [83]. The JE-PIV is also formalin inactivated, but unlike the MBDI vaccine, uses Alum as a adjuvant and has no stabilisers or preservatives like gelatin or thimerosal [83]. The vaccine has moved into phase 3 trials conducted in USA, Europe and Australia with promising outcomes. Studies are also planned for India where Intercell has linked with Biological $\mathrm{E}$ to produce and distribute the vaccine [75].

Inactivated Beijing 1 strain Vero cell derived vaccine: is being developed by Biken and Kaketsuken institute, Japan. A phase 1 study administering the test and conventional MBDI vaccine ( $n=30$ each) showed no SAEs, few mild AEs $(6.7 \%)$ and seroconversion of $100 \%$ (95\% CI, 88\%-100\%) after 3 doses [84]. Immunological agreement with the conventional MBDI vaccine has also been demonstrated and a promising phase 3 trial has also been recently completed [85]. Development appears to be limited to the Japanese market only [75].

\section{CONCLUSIONS}

Significant progress has been made in the effort to control JE and the incidence has declined in many countries. However, JE remains a public health concern, with outbreaks continuing in Asia. Progress has also been made in vaccine development, a key tool to control JE. The MBDI vaccine has played a crucial role in reducing the burden of JE in the region, though limitations of this vaccine have rightly resulted in efforts to develop new and better vaccines. Currently, the live attenuated SA 14-14-2 vaccine is the relatively cheap, easy to produce and administer, safe, and efficacious vaccine. Uptake of the vaccine is increasing in South-Asia region, especially in India. New safe and efficacious vaccines are likely to appear in the market in the next decade. However several key issues remain to be addressed to ensure effective control of JE. Disease surveillance needs to be maintained in countries where incidence has declined or strengthened in endemic countries where outbreaks remain a problem. Cheap, effective and feasible diagnostics are needed to strengthen case detection and reliability of reporting. Rigorous surveillance of vaccine associated adverse events is needed, including in countries that are now

\footnotetext{
${ }^{5}$ Yao, Z.; Dong, G.; Yu, Y. Zhonghau Liu Xing Bing Xue Za Zhi, 1999, 13, 191-3. [Article in Chinese with English Abstract].
} 
commencing large-scale use of the live attenuated SA 14-142 vaccine. Further research to assess the need and timing of booster doses of the live vaccine as well as its use following initial vaccination with the MBDI vaccine would be useful to identify cost effective dosing regimens.

\section{REFERENCES}

[1] WHO SEA/ WPR; PATH. Report of the Bi-regional meeting on Japanese encephalitis. WHO regional office for SEA: New Delhi, 2005.

[2] PATH. Japanese encephalitis initiative. http://www.path.org/ projects/JE_in_depth.php (accessed April 1, 2007).

[3] Zanin, M.P.; Webster, D.E.; Martin, J.L.; Wesselingh, S.L. Expert Rev. Vaccines, 2003, 2, 407-16.

[4] Kimura-Kuroda, J.; Yasui, K. J. Immunol., 1988, 141, 3606-10.

[5] Hombach, J.; Solomon, T.; Kurane, I.; Jacobson, J.; Wood, D. Vaccine, 2005, 23, 5205-11.

[6] Oya, A. Acta Paediatr., 1988, 30, 175-4.

[7] Konishi, E.; Kurane, I.; Mason, P.W.; Shope, R.E.; Kanesa-Thasan, N.; Smucny, J.J.; Hoke, C.H.; Ennis, F.A. Vaccine, 1999, 16, 8429.

[8] WHO. Weekly Epidemiol. Rec., 2006, 81, 325-40.

[9] Tsai, T. Vaccine, 2000, 18, 1-25.

[10] Gingrich, J.B.; Nisalak, A.; Latendresse, J.R.; Pomsdhit, J.; Paisansilp, S.; Hoke, C.H.; Chantalakana, C.; Satayaphantha, C.; Uechiewcharnkit, K. Southeast Asian J. Trop. Med. Public Health, 1987, 18, 558-66.

[11] Sohn, Y.M. Emerg. Infect. Dis., 2000, 6, 17-24

[12] Wu, Y.C.; Huang, Y.S.; Chien, L.J.; Lin, T.L.; Yueh, Y.Y.; Tseng, W.L.; Chang, K.J.; Wang, G.R. Am. J. Trop. Med. Hyg., 1999, 61, 78-84.

[13] Halstead, S.B.; Tsai, T.F. In Vaccines 4th edition. Plotkin \& Orenstein, Ed.; Saunders: Philadelphia, 2004, pp. 919-58

[14] Heymann, D.L. Control of communicable disease manual, $18^{\text {th }}$ ed.; APHA, 2004.

[15] Uppal, P.K. Ann. N. Y. Acad. Sci., 2000, 916, 354-7.

[16] Hoke, C.H.; Vaughn, D.W.; Nisalak, A.; Intralawan, P.; Poolsuppasit, S.; Jongsawas, V.; Titsyakorn, U.; Johnson, R.T. J. Infect. Dis., 1992, 165, 631-7.

[17] Solomon, T.; Dung, N.M.; Wills, B.; Kneen, R.; Gainsborough, M.; Diet, T.V.; Tuy, T.T.; Loan, H.T.; Khanh, V.C.; Vaughn, D.W. White, N.J.; Farrar, J.J. Lancet, 2003, 361, 821-26.

[18] Solomon, T. N. Engl. J. Med., 2006, 355, 869-71.

[19] Mackenzie, J.S. J. Neurovirol., 2005, 11, 434-40.

[20] Bista, M.B.; Shrestha, J.M. J. Nepal Med. Assoc., 2005, 44, 51-6.

[21] Lalitha, K. Indian J. Pediatr., 2004, 71, 707-12.

[22] Bhau, L.; Singh, G.; Gowal, D.; Saxena, S.N.; Kobayashi, M.; Oya, A.; Yoshioka, I. Indian J. Med. Res., 1988, 88, 301-7.

[23] CDC. Outbreak notice: Japanese encephalitis in Uttar Pradesh, Bihar, India and Nepal. $C D C, 2005$.

[24] Liu, W.; Clemens, J.; Yang, J.; Xu Z.Y. Vaccine, 2006, 24, 517882.

[25] Wang, L.H.; Fu, S.H.; Wand, H.Y.; Liang, X.F.; Cheng, J.X.; Jing, H.M.; Cai, G.L.; Li, X.W.; Ze, W.Y.; Lv, X.J.; Wang, H.Q.; Zhang, D.L.; Feng, Y.; Yin, Z.D.; Sun, X.H.; Shui, T.J.; Li, M.H.; Li, Y.X.; Liang, G.D. Emerg. Infect. Dis., 2007, 13, 1124-24.

[26] Ayukawa, R.; Fujimoto, H.; Ayabe, M.; Shoji, H.; Matsui, R.; Iwata, Y.; Fukuda, H.; Ochi, K.; Noda, K.; Ona, Y.; Sakai, K.; Takehisa, Y.; Yasui, K. Jpn. J. Infect. Dis., 2004, 57, 63-6.

[27] Harad, W.; Kuwabara, M.; Kuwayama, M.; Takao, S.; Miyazaki, K. Kansenshogaku Zasshi, 2004, 78, 1020-5.

[28] Marfin, A.A.; Gubler, D.J. Lancet, 2005, 366, 1375-8.

[29] Monath, T.P. Curr. Top. Microbiol. Immunol., 2002, 267, 105-38.

[30] Sakaguchi, M.; Yoshida. M.; Kuroda, W.; Harayama, O.; Matsunaga, Y.; Inouye, S. Vaccine, 1997, 15, 121-2.

[31] Nakayama, T.; Onoda, K. Vaccine, 2007, 25, 570-6.

[32] Yang, S.E.; Pan, M.J.; Tseng, H.F.; Liau, M.Y. Vaccine, 2006, 24, 2669-73.

[33] Hanna, J.N.; Smith, G.A.; McCulloch, B.G.; Taylor, C.T.; Pyke, A.T.; Brookes, D.L. Aust. N.Z. J. Public Health, 2005, 29, 44-7.

[34] Tseng, H.F.; Tan, H.F.; Chang, C.K.; Huang, W.L.; Ho, W.C. Am. J. Infect. Control., 2003, 31, 435-40.

[35] Konishi, E.; Suzuki, T. Vaccine, 2002, 21, 98-107.

[36] Plesner, A.; Ronne, T.; Wachman, H. Vaccine, 2000, 18, 1830-6.
[41] Berg, S.W.; Mitchell, B.S.; Hanson, R.K.; Olafson, R.P.; Williams, R.P.; Tueller, J.E.; Burton, R.J.; Novak, D.M.; Tsai, T.F.; Wignall, F.S. Clin. Infect. Dis., 1997, 24, 265-6.

[42] Nothdurft, H.D.; Jelinek, T.; Marschang, A.; Maiwald, H.; Kapaun, A.; Loscher, T. J. Infect., 1996, 32, 119-22.

[43] Nimmannitya, S.; Hutamai, S.; Kalayanarooj, S.; Rojanasuphot, S. Southeast Asian J. Ttrop. Med. Public Health, 1995, 26, 689-93.

[44] Gowal, D.; Tahlan, A.K. Indian J. Med. Res., 1995, 102, $267-71$.

[45] Robinson, R.; Ruff, T.; Kass, R. J. Travel. Med., 1995, 2, 159-64.

[46] Ohtaki, E.; Matsuishi, T.; Hirano, Y.; Maekawa, K. J. Neurol. Neurosurg. Psychiatry, 1995, 59, 316-7.

[47] Ku, C.C.; King, C.C.; Lin, C.Y.; Hsu, H.C.; Chen, L.Y.; Yueh, Y.Y.; Chang, G.J. J. Med. Virol., 1994, 44, 122-31.

[48] Mohan Rao, C.V.; Risbud, A.R.; Dandawate, C.N.; Umarani, U.B.; Ayachit, V.M.; Rodrigues, F.M.; Pavri, K.M. Indian J. Med. Res., 1993, 97, 53-9.

[49] Poland, J.D.; Cropp, C.B.; Craven, R.B.; Monath, T.P. J. Infect. Dis., 1990, 161, 878-82.

[50] Rojanasuphot, S.; Charoensuk, O.; Kitprayura, D.; Likityingvara, C.; Limpisthien, S.; Boonyindee, S.; Jivariyavej, V.; Ugchusak, K. Southeast Asian J. Trop. Med. Public Health, 1989, 20, 653-4.

[51] Saxena, S.N.; Bhau, L.N.; Singh, G.; Gowal, D.; Sood, Y.K.; Misra, C.N.; Das, B.K. Indian J. Med. Res., 1989, 89, 362-7.

[52] Hoke, C.H.; Nisalak, A.; Sangawhipa, N.; Jatanasen, S.; Laorakapongse, T.; Kotchasenee, S.; Gingrich, J.B.; Latendresse, J.; Fukai, K. N. Engl. J. Med., 1988, 319, 608-14.

[53] Yamada, A.; Imanishi, J.; Juang, R.F.; Fukunaga, T.; Okuno, Y.; Tadano, M.; Baba, K.; Yabuuchi, H. Vaccine, 1986, 4, 32-4.

[54] Henderson, A. J-R. Army Med. Corps, 1984, 130, 188-91.

[55] Juang, R.F.; Okuno, Y.; Fukunaga, T.; Tadano, M.; Fukai, K.; Baba, K.; Tsuda, N.; Yamada, A.; Yabuuchi, H. Biken J., 1983, 26, 25-34.

[56] Sakaguchi, M.; Inouye, S. Vaccine, 1998, 16, 68-9.

[57] Plesner, A.M.; Arlien-Soborg, P.; Herning, M. Eur. J. Neurol., 1998, 5, 479-85.

[58] WHO/ GACVS. Mouse brain derived JE vaccine. http://www.who. int/vacine_safety/topics/japanese_encephalitis/mouse_brain_derive d/en/ (accessed April, 1 2007).

[59] PATH. SA 14-14-2 Japanese encephalitis (JE) vaccine http://www.path.org/vaccineresources/files/SA14142factsheet_03 May07.pdf (accessed April 1, 2007).

[60] WHO expert committee on biological standardization. WHO technical report series 2002, 910, 1-104.

[61] WHO. Weekly Epidemiol. Rec., 2007, 3, 23-4.

[62] Tandan, J.B.; Ohrr, H.; Sohn, Y.M.; Yoksan, S.; Ji, M.; Nam, C.M.; Halstead, S.B. Vaccine, 2007, 25, 5041-45.

[63] Ohrr, H.; Tandan, J.B.; Sohn, Y.M.; Shin, S.H.; Pradhan, D.P.; Halstead, S.B. Lancet, 2005, 366, 1375-8.

[64] Bista, M.B.; Banerjee, M.K.; Shin, S.H.; Tandan, J.B.; Kim, M.H.; Sohn, Y.M.; Ohrr, H.C.; Tang, J.L.; Halstead, S.B. Lancet, 2001, 358, 791-5.

[65] Jia, L.; Wang, Z.; Yu, Y. Chin. Med. J., 2003, 116, 941-3.

[66] Sohn, Y.M.; Parks, M.S.; Rho, H.O.; Chandler, L.J.; Shope, R.E.; Tsai, T.F. Vaccine, 1999, 17, 2259-64.

[67] Tsai, T.F.; Yu, Y.X.; Jia, L.L.; Putvatana, R.; Zhang, R.; Wang, S.; Halstead, S.B. J. Infect. Dis., 1998, 177, 221-3.

[68] Liu, Z.L.; Hennessy, S.; Strom, B.L.; Tsai, T.F.; Wan, C.M.; Tang, S.C.; Xiang, C.F.; Bilker, W.B.; Pan, X.P.; Yao, Y.J.; Xu, Z.W.; Halstead, S.B. J. Infect. Dis., 1997, 176, 1366-9.

[69] Hennessy, S.; Liu, Z.; Tsai, T.F.; Wan, C.M.; Tang, S.C.; Xiang, C.F.; Bilker, W.B.; Pan, X.P.; Yao, Y.J.; Xu, Z.W.; Halstead, S.B. Lancet, 1996, 347, 1583-6.

[70] Ma, X.; Yu, Y.X.; Wang, S.G. Chin. J. Biol., 1993, 6, 188-91.

[71] Xin, Y.Y.; Ming, Z.G.; Peng, G.Y.; Jian, A.; Min, L.H. Am. J. Trop. Med. Hyg., 1988, 39, $214-7$. 
[72] E biology news. China to supply anti-Japanese encephalitis vaccine to India. http://www.ebiologynews.com/2100.html (accessed April 1, 2007).

[73] Luo, D.; Yin, H.; Xili, L.; Song, J.; Wang, Z. Southeast Asian J. Trop. Med. Public Health, 1994, 25, 643-6.

[74] Ding, D.; Kilgore, P.E.; Clemens, J.D.; Wei, L.; Zhi-Yi, X. Bull. World Health Organ., 2003, 81, 334-42.

[75] PATH. Japanese encephalitis vaccines at a glance. http://www.path.org/projects/japanese_encephalitis_project_atagla nce.php (accessed April 1, 2007).

[76] Siraprapasiri, T.; Sawaddiwudhipong, W.; Rojanasuphot, S. Southeast Asian J. Trop. Med. Public Health, 1997, 28, 143-8.

[77] Suraratdecha, C.; Jacobson, J.; Sivalenka, S.; Narahari, D. J. Pharm. Finance, Econ. Policy, 2006, 15, 21-40.

[78] Guirakhoo, F.; Zhang, Z.X.; Chambers, T.J.; Delagrave, S.; Arroyo, J.; Barrett, A.D.; Monath, T.P. Virology, 1999, 257, 363-72.

[79] Monath, T.P.; Soike, K.; Levenbrook, I.; Zhang, Z.X.; Arroyo, J.; Delagrave, S.; Myers, G.; Barret, A.D.; Shope, R.E.; Ratterree, M.; Chambers, T.J.; Guirakhoo, F. Vaccine, 1999, 17, 1869-82.

[80] Monath, T.P.; McCarthy, K.; Bedford, P.; Johnson, C.T.; Nichols, R.; Yoksan, S.; Marchesani, R.; Knauber, M.; Wells, K.H.; Ayyoyo, J.; Guiakhoo, F. Vaccine, 2002, 20, 1004-18.
[81] Monath, T.P.; Guirakhoo, F.; Nichols, R.; Yoksan, S.; Schrader, R.; Murphy, C.; Blum, P.; Woodward, S.; McCarthy, K.; Mathis, D.; Johnson, C.; Bedford, P. J. Infect. Dis., 2003, 188, 1213-30.

[82] Srivastava, A.K.; Putnak, J.R.; Lee. S.H.; Hong, S.P.; Moon, S.B.; Barvir D.A.; Zhao, B.; Olson, R.A.; Kim, S.O.; Yoo, W.D.; Towle, A.C.; Vaughn, D.W.; Innis, B.L.; Eckels, K.H. Vaccine, 2001, 19, 4557-65.

[83] Lyons, A.; Kanesa-thasan, N.; Kuschner, R.A.; Eckels, K.H.; Putnak, R.; Sun, W.; Burge, R.; Towle, A.C.; Wilson, P.; Tauber, E.; Vaughn, D.W. Vaccine, 2007, 25, 3445-53.

[84] Kuzuhara, S.; Nakamura, H.; Havashida, K.; Obata, J.; Abe, M.; Sonoda, K.; Nishiyama, K.; Sugawara, K.; Takeda, K.; Honda, T.; Matsui, H.; Shigaki, T.; Kino, Y.; Mizokami, H.; Tanaka, M.; Mizuno, K.; Ueda, K. Vaccine, 2003, 21, 4519-26.

[85] Abe, M.; Shiosaki, K.; Hammar, L.; Sonoda, K.; Xing, L.; Kuzuhara, S.; Kino, Y.; Holland Cheng, R. Virus Res., 2006, 121, 152-60.

(C) Balasegaram and Daniel Chandramohan; Licensee Bentham Open.

This is an open access article distributed under the terms of the Creative Commons Attribution License (http://creativecommons.org/license/by/2.5/), which permits unrestrictive use, distribution, and reproduction in any medium, provided the original work is properly cited. 